University of Nebraska - Lincoln

DigitalCommons@University of Nebraska - Lincoln

\title{
GROWING RICE GRAIN WITH CONTROLLED CADMIUM CONCENTRATIONS
}

Urszula Kukier

USDA-ARS, kukieru@ba.ars.usda.gov

Rufus L. Chaney

USDA-ARS

Follow this and additional works at: https://digitalcommons.unl.edu/usdaarsfacpub

Part of the Agricultural Science Commons

Kukier, Urszula and Chaney, Rufus L., "GROWING RICE GRAIN WITH CONTROLLED CADMIUM CONCENTRATIONS" (2002). Publications from USDA-ARS / UNL Faculty. 565.

https://digitalcommons.unl.edu/usdaarsfacpub/565

This Article is brought to you for free and open access by the U.S. Department of Agriculture: Agricultural Research Service, Lincoln, Nebraska at DigitalCommons@University of Nebraska - Lincoln. It has been accepted for inclusion in Publications from USDA-ARS / UNL Faculty by an authorized administrator of DigitalCommons@University of Nebraska - Lincoln. 


\title{
GROWING RICE GRAIN WITH CONTROLLED CADMIUM CONCENTRATIONS
}

\author{
Urszula Kukier* and Rufus L. Chaney \\ USDA-ARS, Animal and Natural Resources Institute, \\ Bldg. 007, BARC-West, Beltsville, MD 20705-2350
}

\begin{abstract}
Two solution studies were conducted a) to investigate the uptake of zinc $(\mathrm{Zn})$ and cadmium $(\mathrm{Cd})$ by rice plants (Oryza sativa L.) and interaction between these elements, and b) to determine experimental conditions for growing rice grain with desired $\mathrm{Cd}$ concentration for an animal feeding study. In both studies, free metal activities of cadmium and cationic microelements were buffered by an excess of chelating agents. The first study was a factorial design with two $\mathrm{Zn}$ levels $(1.0$ and $3.89 \mu \mathrm{M})$ and four Cd levels $(0.81,1.44,2.56$ and $4.55 \mu \mathrm{M})$ in the solution. In the second study, rice was grown in two solutions of different microand macro-element compositions and three $\mathrm{Cd}$ levels $(0.0,0.5$, and $2.0 \mu \mathrm{M})$. In the first study, solution $\mathrm{Zn}$ concentration of $3.89 \mu \mathrm{M}$ and corresponding free metal activity $\left(\mathrm{pZn}^{2+}\right)$ of 6.00 was toxic to young rice plants. With time, $\mathrm{Zn}$ concentrations in rice plants decreased while $\mathrm{Cd}$ concentrations increased. Toxic concentration of $\mathrm{Cd}$ in roots (about $100 \mathrm{mg} \mathrm{kg}^{-1}$ ) associated with
\end{abstract}

*Corresponding author. E-mail: kukieru@ba.ars.usda.gov

1793

Copyright (C) 2002 by Marcel Dekker, Inc.

www.dekker.com

This article is a U.S. government work, and is not subject to copyright in the United States. 
a $20 \%$ reduction in the root dry matter occurred at the free $\mathrm{Cd}^{2+}$ activities in the solution $\left(\mathrm{pCd}^{2+}\right)$ in the range of 10.25-9.75. Sufficient $\mathrm{Zn}$ level in plants slightly stimulated $\mathrm{Cd}$ transfer from roots to shoots as opposed to barely sufficient or slightly deficient $\mathrm{Zn}$ concentration in shoots. However, the better $\mathrm{Zn}$ status in plants clearly diminished severity of $\mathrm{Cd}$ toxicity symptoms in shoots. The use of nutrient solutions adapted for rice growth allowed the rice grown in the second experiment to produce grain under controlled conditions. Cadmium in the brown rice grain was 0.1 to $0.8 \mathrm{mg} \mathrm{kg}^{-1}$, covering the range needed for feeding experiments relevant to rice $\mathrm{Cd}$ risk to humans. Composition of the nutrient solutions, in addition to solution Cd level, had a significant effect on $\mathrm{Cd}$ concentration in grain. Correlation of grain $\mathrm{Cd}$ concentration with solution $\mathrm{Cd}^{2+}$ activity was much stronger than with total solution $\mathrm{Cd}$. Results of both experiments supported hypothesis that $\mathrm{Cd}$ uptake and transport within rice plants is an active process.

\section{INTRODUCTION}

Contamination of rice grain with $\mathrm{Cd}$ was found to cause adverse health effects in subsistence rice consumers, ${ }^{[1]}$ which stimulated extensive research on Cd uptake by rice plants conducted mostly by Japanese scientists. Because increased levels of $\mathrm{Zn}$ in plant derived food inhibits absorption of $\mathrm{Cd}$ by animal consumers, ${ }^{[2,3]}$ special attention has been paid to $\mathrm{Zn}-\mathrm{Cd}$ interactions in rice. Both field and nutrient solution studies were conducted. It has been established that although translocation of $\mathrm{Cd}$ from roots to shoots in rice is small, the level of $2-6 \mathrm{mg} \mathrm{Cd} \mathrm{kg}{ }^{-1}$ soil caused grain $\mathrm{Cd}$ to exceed $1 \mathrm{mg} \mathrm{kg}^{-1}$, which subsequently caused $\mathrm{Cd}$ disease in rice consumers. ${ }^{[4]}$ Other studies demonstrated that consumption of food derived from crops, other than rice, grown in soils containing $50-150 \mathrm{mg} \mathrm{Cd} \mathrm{kg}^{-1}$ did not cause any adverse health effects despite considerable chronic $\mathrm{Cd}$ intake. ${ }^{[5]}$ Rice grain is quite low in iron $(\mathrm{Fe}), \mathrm{Zn}$, and $\mathrm{Ca}$ as compared to soybean and wheat, ${ }^{[6]}$ and much of grain $\mathrm{Zn}, \mathrm{Fe}$, and $\mathrm{Ca}$ are removed in polishing of brown rice. ${ }^{[7]}$ Low levels of these elements in food, or marginal nutritional status of the consumer's usual diet, causes increased intestinal absorption and accumulation of $\mathrm{Cd}{ }^{\left[{ }^{8-10]}\right.}$ Phytate, fiber and other components of a diet can also affect $\mathrm{Cd}$ bioavailability and risk. Factors regulating $\mathrm{Cd}$ bioavailability in food are discussed in detail by Fox ${ }^{[11]}$ and Chaney et al., ${ }^{[12]}$ who also postulated that dietary Cd risk assessment based on subsistence rice consumers overestimated potential for 
adverse effects of food $\mathrm{Cd}$ in societies whose diet is based on other staple foods.

Animal feeding studies comparing $\mathrm{Cd}$ bioavailability from various staple foods, including rice, have been proposed to elucidate this issue. Such a study should utilize grain with intrinsic labeled $\mathrm{Cd}$ rather than labeled $\mathrm{Cd}$ added as a salt to animal diet, as it was shown that bioavailability of metals added to a diet as salts differs from that of intrinsic forms. ${ }^{[3,9,13]}$ Therefore, the first objective of our study was to test conditions for growing rice grain of desired $\mathrm{Cd}$ concentration, between 0.5 and $1.0 \mathrm{mg} \mathrm{kg}^{-1}$. Hydroponic culture was the method of choice because, for equal $\mathrm{Cd}$ uptake by rice, much lower concentrations of labeled $\mathrm{Cd}$ would be required in solution than in soil, and by that, the amount of radioactive waste would be minimized. This study would calibrate plant response to solution $\mathrm{Cd}$ and $\mathrm{Zn}$ levels so that labeled grain could be produced in subsequent experiments; non-radioactive $\mathrm{Cd}$ was used to test the method. In addition to the primary goal, growing rice grain for a feeding trial, the hydroponic experiment was utilized to study various aspects of $\mathrm{Cd}$ uptake by rice plants.

Most nutrient solution studies on $\mathrm{Cd}$ and other trace metal uptake by rice were conducted in 1970-1980 decade in Japan and yielded in a detailed knowledge of these phenomena. ${ }^{[14,15]}$ Trace metals in these solutions were introduced in the form of inorganic salts. Free metal activities in these solutions were highly dependent on solution $\mathrm{pH}$, which will be continuously changed by the action of plant roots. Recently developed chelator-buffered nutrient solution techniques utilize a variety of chelating agents which allow independent variation of the activity of each cationic micronutrient and buffer it at the target level across a broad range of $\mathrm{pH}^{[16]}$ This has a special advantage when the effect of $\mathrm{Cd}$ on the uptake of other trace metals is of interest. The excess of chelator buffers a constant free metal activity in the solution despite metal uptake by roots.

Two experiments were conducted. In the first experiment, an attempt was made to grow rice grain with various levels of intrinsic $\mathrm{Cd}$ and $\mathrm{Zn}$, as $\mathrm{Zn}$ was proven, although not unequivocally, to have pronounced effect on $\mathrm{Cd}$ uptake by plants and intestinal absorption of $\mathrm{Cd}$ by animals. This experiment failed to produce grain. The second experiment, which utilized two growth solutions already tested by other scientists (M. Chino and M. Grusak, personal communication) for their suitability for the rice grain production, was successful. In both experiments, $\mathrm{Cd}$ and essential microelements in the growth solutions were buffered by the excess of chelators, which was a novel approach in comparison to other hydroponic studies with rice. The specific questions addressed in this paper are 1) the effect of $\mathrm{Zn}$ on Cd uptake and toxicity in rice plants, 2) transfer of $\mathrm{Cd}$ and essential trace metals from roots to shoots, 3) transfer of $\mathrm{Cd}, \mathrm{Zn}$ and other nutrients to rice grain. 


\section{MATERIALS AND METHODS}

\section{Solution Composition and Plant Growth Conditions: Experiment I}

The experiment was arranged as a factorial design with two levels of $\mathrm{Zn}$ in the nutrient solution and four levels of $\mathrm{Cd}$. Zinc was added as $\mathrm{ZnSO}_{4}$ at concentrations of 1.0 and $3.89 \mu \mathrm{M}$ and corresponding activities $\left(\mathrm{pZn}^{2+}\right) 6.58$ and 6.00. $\mathrm{CdSO}_{4}$ was added to achieve concentrations of $0.81,1.44,2.56$ and $4.55 \mu \mathrm{M}$ of total $\mathrm{Cd}$ in the nutrient solution and the following corresponding free metal activities $\left(\mathrm{pCd}^{2+}\right) 10.25,10.00,9.75$, and 9.50. Each $\mathrm{Cd}-\mathrm{Zn}$ treatment had three replicates randomly distributed within three blocks. Free metal activities and solution speciation were calculated using GEOCHEM-PC Version 2. ${ }^{[17]}$ The 0.5 strength Hoagland solution with concentration of $\mathrm{P}$ lowered in comparison to the original Hoagland solution was employed as a basal solution in the study. Micronutrient concentrations in the solution are provided in Table 1. The EGTA ([ethylenebis(oxyethylenenitrilo)]tetraacetic acid) was added to supply $50 \mu \mathrm{M}$ in excess of the sum of manganese $(\mathrm{Mn})$, copper $(\mathrm{Cu})$, nickel $(\mathrm{Ni})$, cobalt $(\mathrm{Co}), \mathrm{Cd}$ and $\mathrm{Zn}$ concentrations to buffer microelement cation activities. Ferrous iron was supplied as a ferrozine (FZ) (3-(2-pyridyl)-5,6-diphenyl-1,2,4-triazine-4'4' disulfonic acid) complex, which buffered the free $\mathrm{Fe}^{2+}$ activity $\left(\mathrm{pFe}^{2+}\right)$ at 8.5 . Corresponding concentration of Fe in the nutrient solution was $16.1 \mu \mathrm{M}$ while that of FZ was $80 \mu \mathrm{M}$, which provided $30 \mu \mathrm{M}$ excess to buffer free $\mathrm{Fe}^{2+}$ activity. Solution $\mathrm{pH}$ was buffered at 6.2 by $2.0 \mathrm{mM}$ MES (2-(4-morpholino)ethanesulfonic acid). Depending on plant age, 100 or $200 \mu \mathrm{M} \mathrm{NH} \mathrm{NNO}_{3}$ along with 10 or $20 \mu \mathrm{M} \mathrm{KH_{2 }} \mathrm{PO}_{4}$ was added to the solution on a daily basis.

Rice seeds (cultivar Jefferson) were germinated in standard germination paper saturated with 0.5 strength Hoagland solution. Five days after starting germination, seedlings were transferred to $8 \mathrm{~L}$ polyethylene buckets, each holding 20 plants grouped in five bundles of four seedlings supported by polyurethane foam. Plants were grown in a growth chamber with temperature maintained at $25 / 20 \mathrm{EC}$ day/night, relative humidity $70 / 90 \%$ day/night, and $16 / 8 \mathrm{~h}$ light/dark. A photosynthetically active radiation of $300 \mu \mathrm{mol} \mathrm{m}^{-2} \mathrm{~s}^{-1}$ was provided by mixed fluorescent and incandescent lamps. Solution $\mathrm{pH}$ was monitored on a daily basis. If solution $\mathrm{pH}$ was shifted by the root action to 0.5 unit above or below the target value, $100 \mu \mathrm{M}$ daily additions of $\left(\mathrm{NH}_{4}\right)_{2} \mathrm{SO}_{4}$ or $\mathrm{Ca}\left(\mathrm{NO}_{3}\right)_{2}$ were employed instead of $\mathrm{NH}_{4} \mathrm{NO}_{3}$ addition in order to lower or raise the $\mathrm{pH}$ of solution. Continuous aeration of the solutions was provided and deionized water was added to maintain a constant volume of the solution in each bucket. Solutions were completely replaced every two weeks. One bundle was harvested after 26 days (harvest I), and the another bundle was harvested after 67 days (harvest II) of growth in the nutrient solution. Rice plants grown in this study never produced grain. 


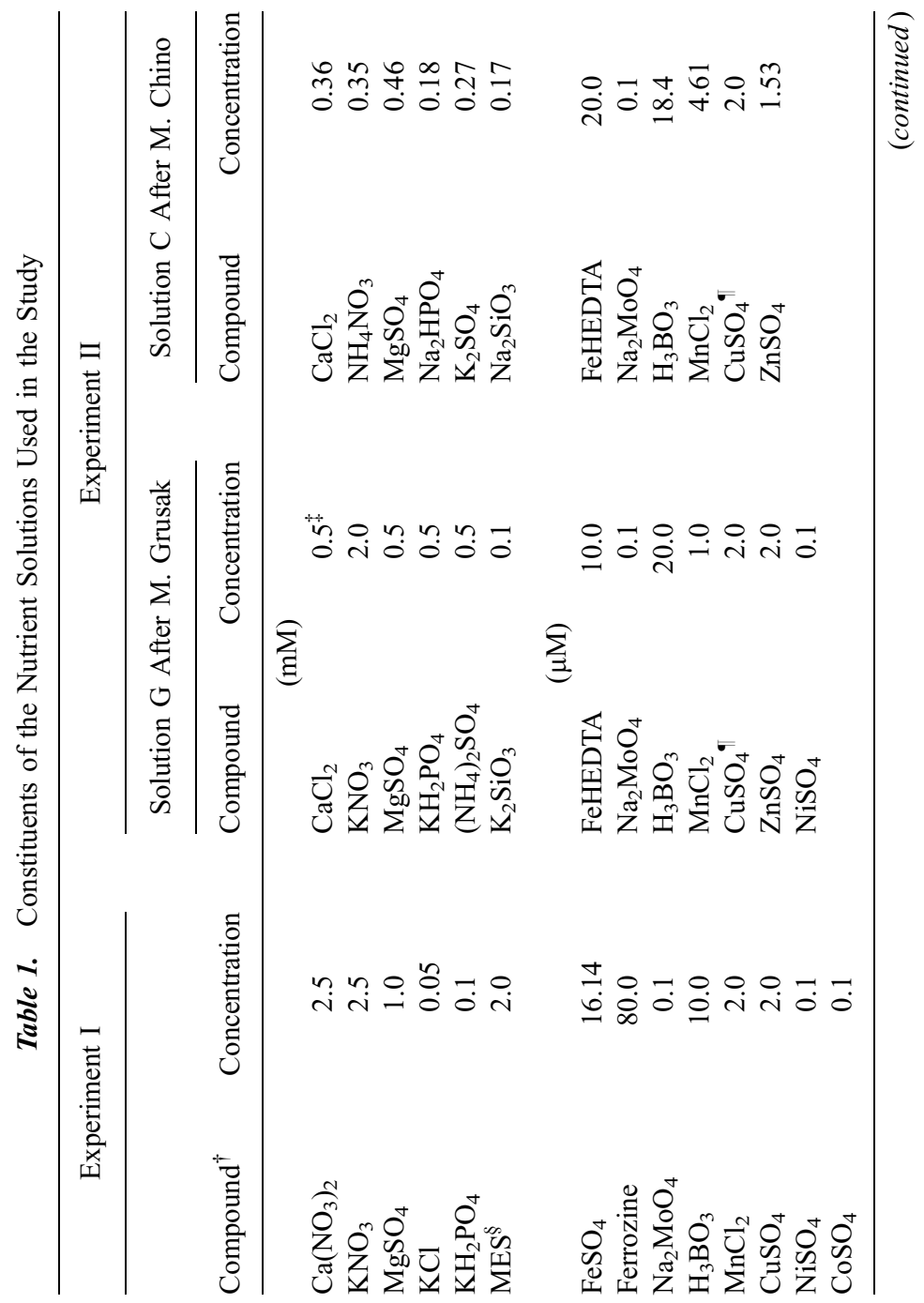




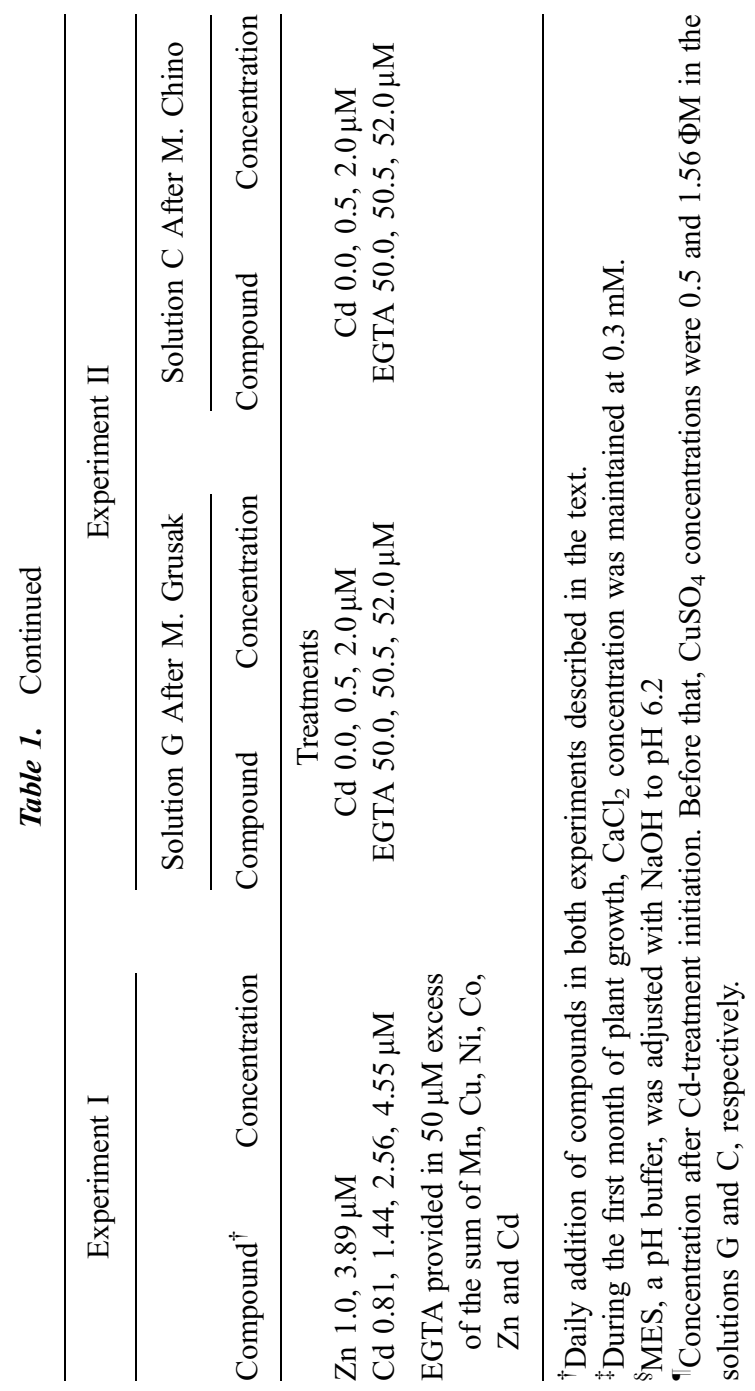


After 89 days of growth in nutrient solution, when no signs of panicle formation were observed, all remaining plants were harvested and the experiment was terminated (harvest III).

At each harvest, plants were separated into roots and shoots. In order to remove extracellular $\mathrm{Cd}$, roots were rinsed in three consecutive batches of 0.5 strength Hoagland solution, with $\mathrm{KH}_{2} \mathrm{PO}_{4}$ excluded, and blotted with paper towels.

\section{Solution Composition and Plant Growth Conditions: Experiment II}

Numerous reasons of the failure of grain production in the Experiment I were considered such as composition of the growth medium and plant growth conditions including day length, day/night temperature regime and number of plants grown in one bucket. For some rice cultivars the length of day is crucial for the initiation of reproductive phase of growth. Although to our knowledge the Jefferson cultivar is not a short day variety, in Experiment II, the day length was cut to 14 hours. Temperature was set at $30 / 25 \mathrm{EC}$ day/night. At these temperatures, the highest attainable relative humidity was $20 / 90 \%$ day/night. Light intensity was maintained at $300 \mu \mathrm{mol} \mathrm{m}^{-2} \mathrm{~s}^{-1}$. Solutions were continuously aerated. The number of plants per bucket was reduced from 20 to 4 . In this experiment, two nutrient solutions, previously successfully used by other scientists (M. Chino and M. Grusak, personal communication) to obtain rice grain in hydroponics experiments, were used; minor modifications were made to take into account supply of Fe to grasses, and buffering $\mathrm{Cd}$. Composition of these solutions is presented in Table 1. Grusak's method originally employed a recirculating hydroponic system much different from our static solution experiment but we attempted to match solution composition as closely as possible. The experiment was a factorial design with two growth solutions, $G$ (after Grusak) and C (after Chino) and three Cd levels 0.0, 0.50 and 2.00 ФМ. Cadmium was supplied as EGTA complex. Free $\mathrm{Cd}^{2+}$ activity was buffered by $50 \mu \mathrm{M}$ excess of EGTA. Control solutions $(0.0 \mu \mathrm{M} \mathrm{Cd})$ also received $50 \mu \mathrm{M}$ EGTA. Iron in solutions $\mathrm{G}$ and $\mathrm{C}$ was applied as FeHEDTA ( $\mathrm{N}-(2$-hydroxyethyl) ethylenedinitrilotriacetic acid) complex without an excess of the HEDTA. During the first 66 days after transplanting to the nutrient solutions, plants were grown without any $\mathrm{Cd}$ addition. Cadmium treatments were initiated on the 67 th day when most of the plants grown in the solution $\mathrm{C}$ entered flowering stage and plants grown in solution $\mathrm{G}$ reached boot stage. Treatments were arranged in three completely randomized blocks; further, the location of the blocks in the growth chamber was rotated three times during the experimental period. After initiation of $\mathrm{Cd}$ treatments, $\mathrm{Cu}$ concentration was increased in both $\mathrm{G}$ and $\mathrm{C}$ solutions to 
$2 \mu \mathrm{M}$ to compensate for $\mathrm{Cu}$ binding by EGTA. MES was not used as a $\mathrm{pH}$ buffer, instead, $\mathrm{pH}$ was measured twice a day and adjusted by the addition of appropriate volume of $0.1 \mathrm{M} \mathrm{NaOH}$ or $\mathrm{HCl}$ solution. Before the initiation of Cd treatments, pH's of the solutions $\mathrm{G}$ and $\mathrm{C}$ were maintained at $6.0(+0.2,-0.7)$ and 5.5 $(+0.2 ;-0.7)$, respectively, as recommended. Starting with the Cd treatments, $\mathrm{pH}$ of both solutions was maintained at $6.0(+0.2 ;-0.7)$. On several occasions, a few hours after changing solutions, $\mathrm{pH}$ dropped by more than one unit due to rapid uptake of $\mathrm{NH}_{4}{ }^{+}$ion by plants with concomitant release of $\mathrm{H}^{+}$by roots. Calculation of solution speciation using Geochem-PC revealed a possibility of the precipitation of ferric phosphate in the solution $\mathrm{G}$, at $\mathrm{pH}$ higher than 6.0. Acidification of the solution caused by a root action would cause a dissolution of this precipitate. Postharvest analysis of the roots confirmed that precipitation of a ferric phosphate in the solution $\mathrm{G}$ was a marginal problem, if any, because total $\mathrm{Fe}$ in the roots of plants $\mathrm{G}$ was lower than in the roots of plants $\mathrm{C}$, and computed speciation of the solution $\mathrm{C}$ did not predict any precipitation within a $\mathrm{pH}$ range

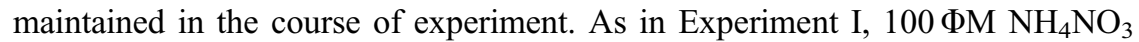
and $20 \Phi \mathrm{M} \mathrm{KH} \mathrm{KO}_{4}$ rates were supplied as a daily addition. The rates were doubled during the period of the most intense plant growth. During the boot stage and during flowering and grain formation, supplemental $\mathrm{Cd}$ and nutrients equal to $10 \%$ of each $\mathrm{Cd}$ treatment as well as $10 \%$ of the macro and microelement rates were added to each bucket between solution changes to compensate for plant uptake. During the first 42 days of growth, nutrient solutions were changed every 7-9 days. Then, frequency of solution changes was increased to every 4-5 days, and at the end of experiment, decreased again to every 6-7 days. Plants $C$ were harvested after 108 days of growth in the nutrient solution. Plants grown in solution $\mathrm{G}$ were harvested 8 days later because they entered their reproductive phase later than plants grown in solution C. At harvest, the number of tillers produced by each plant was counted and the length of the longest tiller and the longest root in each plant measured. Plants were separated into roots, leaves, flag leaves, stems and ears. Ears were further separated to brown rice grain, rachi branches and seed covers. At harvest, roots were rinsed in three consecutive batches of $0.25 \mathrm{mM} \mathrm{Ca}\left(\mathrm{NO}_{3}\right)_{2}$ and $\mathrm{KNO}_{3}$ solution followed by immersing in deionized water for a few seconds, and blotted in paper towels.

\section{Plant Tissue Analysis}

Plants were oven-dried at $65^{\circ} \mathrm{C}$ to constant weight and dry weights were recorded. Plant materials were ground in a stainless steel Wiley mill, weighed into glass beakers and ashed in a muffle furnace at $450 \mathrm{EC}$ for $16 \mathrm{hr}$. Blanks were included every 10 samples. Ashed plant samples were digested in $2 \mathrm{~mL}$ of concentrated $\mathrm{HNO}_{3}$ on a hot plate and then refluxed for $2 \mathrm{hr}$ with $10 \mathrm{~mL}$ of $3 \mathrm{M}$ 
HCl. Digested samples were filtered through Whatman 40 filter paper and diluted with $0.1 \mathrm{M} \mathrm{HCl}$ to a volume of $25 \mathrm{~mL}$. Molybdenum (Mo), $\mathrm{Zn}, \mathrm{Cd}$, phosphorus $(\mathrm{P})$, copper $(\mathrm{Cu}), \mathrm{Mn}, \mathrm{Fe}$, magnesium $(\mathrm{Mg})$, calcium $(\mathrm{Ca})$, and potassium $(\mathrm{K})$ were determined by inductively coupled plasma spectrometry (ICP) using Co as an internal standard added to each sample and standard solutions at $40 \mathrm{mg} \mathrm{L}^{-1}$. $\mathrm{Cd}$ was also determined using AAS with deuterium background correction. The NBS standard reference material 1573a tomato leaves was digested every 20 samples for quality control.

\section{Statistical Analysis}

In Experiment I, repeated measures analysis of variance ${ }^{[18]}$ was employed to test significance of the $\mathrm{Zn}$ and $\mathrm{Cd}$ treatments in relation to time of harvest. For means separation, either Duncan's multiple range test or the paired $t$-test were performed within the subsets of data from each harvest.

Statistical analysis of the results obtained in the Experiment II was performed using analysis of variance and $t$-test as well as regression analysis. ${ }^{[18]}$

\section{RESULTS OF EXPERIMENT I}

\section{Plant Yield and Cadmium and Zinc Concentrations}

Several levels of $\mathrm{Cd}$ in the growth medium combined with two $\mathrm{Zn}$ levels and three harvest dates provided data on the dynamics of uptake of $\mathrm{Cd}$ and other elements.Concentrations of $\mathrm{Zn}$ in vegetative rice tissues were dependent on the $\mathrm{Zn}$ level in the growth medium $(P<0.001)$ and harvest date $(P<0.001)$ (Fig. 1). Cadmium treatments did not have any statistically significant effect on $\mathrm{Zn}$ concentration in plant tissues. The highest concentrations of $\mathrm{Zn}$ in roots and shoots occurred at the early harvest. At $\mathrm{pZn}^{2+}$ activity of 6.00 , concentrations of $\mathrm{Zn}$ in shoots, at harvest I, slightly exceeded $100 \mathrm{mg} \mathrm{kg}^{-1}$, which is the toxicity threshold for rice plants. ${ }^{[19]}$ The higher level of $\mathrm{Zn}$ in the nutrient solution inhibited growth of roots and shoots at the early stage of growth (Table 2) As Zn concentration in shoots decreased in the course of experiment, the inhibitory effect of the higher $\mathrm{Zn}$ treatment on plant growth disappeared. At $\mathrm{pZn}^{2+}$ activity of 6.58 , the $\mathrm{Zn}$ concentrations in shoots were significantly lower than at $\mathrm{pZn}^{2+}$ of 6.00. At the lower $\mathrm{Zn}$ treatment, shoot $\mathrm{Zn}$ level that was well within the sufficiency range at harvest $\mathrm{I}$, dropped to about $15 \mathrm{mg} \mathrm{kg}^{-1}$ which is the sufficiency threshold ${ }^{[20]}$ at harvests II and III. Zinc translocation from roots to shoots was inhibited at the higher $\mathrm{Zn}$ treatment. The stronger inhibition was recorded at the first harvest but the effect was still statistically significant at the 

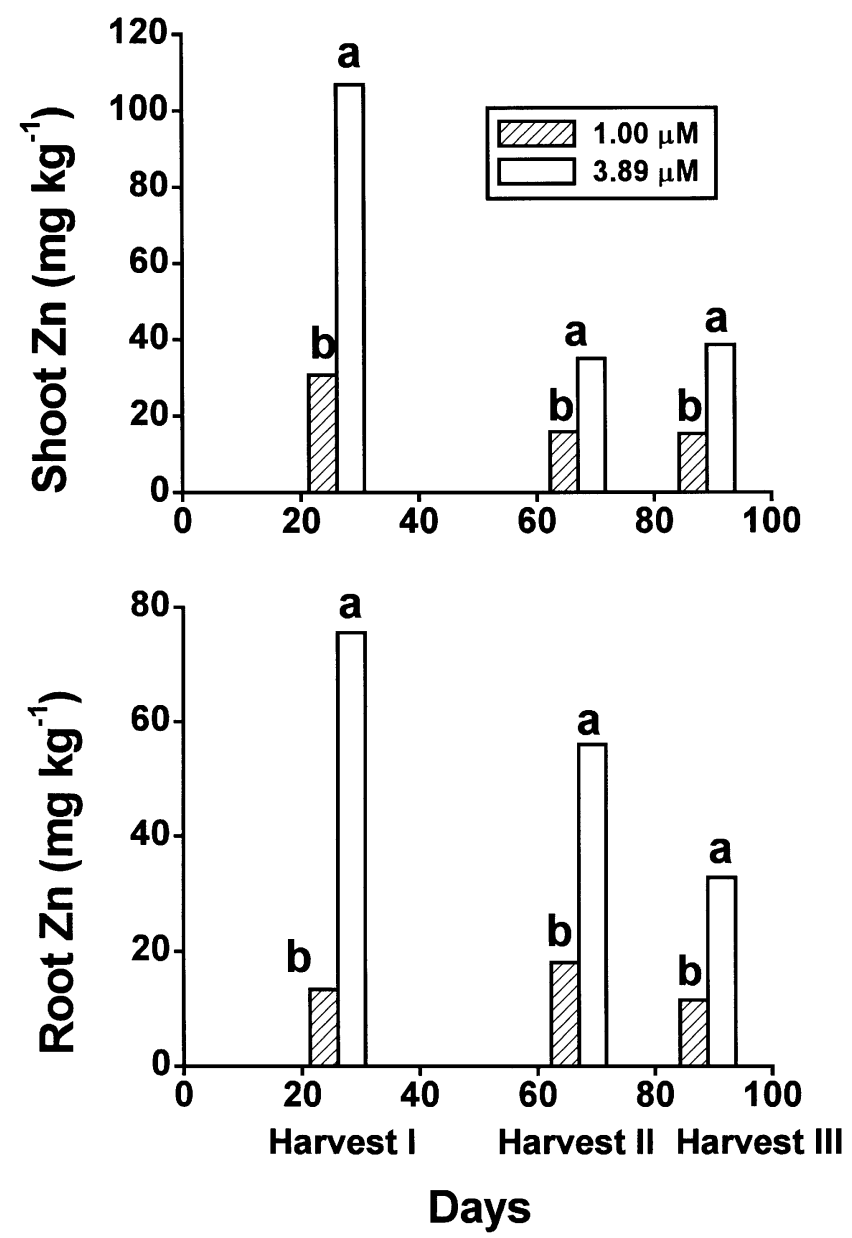

Figure 1. The effect of $\mathrm{Zn}$ level in nutrient solution and harvest date on $\mathrm{Zn}$ concentrations in rice shoots and roots. Different letters above the bars, within the same harvest date, indicate significant difference $(P<0.05)$ between $\mathrm{Zn}$ treatments according to $t$-test.

second harvest. At the first harvest, $\mathrm{Zn}$ shoot-to-root ratio was 2.3 and 1.4 for the low and high $\mathrm{Zn}$ level in nutrient solution, respectively.

Cadmium concentrations in the roots and shoots of rice plants increased almost linearly with increase of $\mathrm{Cd}$ level in solution (Fig. 2). The $\mathrm{Cd}$ concentrations in roots and shoots were relatively stable during the first 67 days of plant growth (harvests I and II) and then rapidly increased during the 
Table 2. The Effect of $\mathrm{Zn}$ and Cd Treatments on Yield of Rice Shoots and Roots

\begin{tabular}{|c|c|c|c|c|c|c|}
\hline \multirow[b]{2}{*}{$\begin{array}{l}\text { Zn and Cd } \\
\text { Treatments }(\mu \mathrm{M})\end{array}$} & \multicolumn{3}{|c|}{ Shoot Yield (g/Bundle) } & \multicolumn{3}{|c|}{ Root Yield (g/Bundle) } \\
\hline & $\begin{array}{c}\text { Harvest } \\
\text { I }\end{array}$ & $\begin{array}{c}\text { Harvest } \\
\text { II }\end{array}$ & $\begin{array}{c}\text { Harvest } \\
\text { III }\end{array}$ & $\begin{array}{c}\text { Harvest } \\
\text { I }\end{array}$ & $\begin{array}{c}\text { Harvest } \\
\text { II }\end{array}$ & $\begin{array}{c}\text { Harvest } \\
\text { III }\end{array}$ \\
\hline Zn $1.0 \mathrm{Cd} 0.81$ & $3.47 \mathrm{a}^{\dagger}$ & $19.5 \mathrm{a}$ & $23.4 \mathrm{a}$ & $0.759 \mathrm{a}$ & $2.70 \mathrm{a}$ & $2.87 \mathrm{a}$ \\
\hline Zn $1.0 \mathrm{Cd} 1.44$ & $3.80 \mathrm{a}$ & $14.4 \mathrm{a}$ & $23.1 \mathrm{a}$ & $0.858 \mathrm{a}$ & $1.96 \mathrm{~b}$ & $3.18 \mathrm{a}$ \\
\hline Zn $1.0 \mathrm{Cd} 2.56$ & $3.85 \mathrm{a}$ & $17.8 \mathrm{a}$ & $22.1 \mathrm{a}$ & $0.831 \mathrm{a}$ & $2.02 \mathrm{~b}$ & $2.53 \mathrm{a}$ \\
\hline $\mathrm{Zn} 1.0 \mathrm{Cd} 4.55$ & $3.90 \mathrm{a}$ & $14.8 \mathrm{a}$ & $27.6 \mathrm{a}$ & $0.786 \mathrm{a}$ & $2.11 \mathrm{ab}$ & $2.65 \mathrm{a}$ \\
\hline Zn 3.89 Cd 0.81 & $2.24 b$ & $16.7 \mathrm{a}$ & $22.1 \mathrm{a}$ & $0.453 b$ & $2.19 \mathrm{a}$ & $3.16 \mathrm{a}$ \\
\hline Zn 3.89 Cd 1.44 & $2.81 \mathrm{~b}$ & $14.4 \mathrm{a}$ & $26.7 \mathrm{a}$ & $0.609 \mathrm{~b}$ & $2.07 \mathrm{~b}$ & $3.40 \mathrm{a}$ \\
\hline Zn 3.89 Cd 2.56 & $2.43 b$ & $17.4 \mathrm{a}$ & $22.0 \mathrm{a}$ & $0.488 \mathrm{~b}$ & $1.98 \mathrm{~b}$ & $1.93 \mathrm{a}$ \\
\hline Zn 3.69 Cd 4.55 & $2.56 \mathrm{~b}$ & $12.8 \mathrm{a}$ & $23.3 \mathrm{a}$ & $0.370 \mathrm{~b}$ & $1.51 \mathrm{~b}$ & $2.40 \mathrm{a}$ \\
\hline
\end{tabular}

†Means within a column followed by the same letter are not significantly different according to the Duncan multiple range test $(P<0.05)$.

further 21 days (harvest III). The effect of time was highly significant $(P<0.001)$. At harvest I, Cd level in roots approached or exceeded the toxicity threshold of $100 \mathrm{mg} \mathrm{kg}^{-1}[19]$ at the two highest $\mathrm{Cd}$ levels in solution $\left(\mathrm{pCd}^{2+}=9.75\right.$ and 9.50). At harvest II (67 days), the inhibitory effect of Cd treatment on the root growth was apparent while the shoot biomass remained unaffected (Table 2). At the higher $\mathrm{Zn}$ concentration in the solution, a linear relationship between the root dry matter and root $\mathrm{Cd}$ concentrations was observed: root yield $=-0.0048$ (root Cd) +2.34 .

Cadmium concentration in roots corresponding with $20 \%$ reduction of the root dry matter calculated from this equation was $117 \mathrm{mg} \mathrm{kg}^{-1}$ which fairly well agrees with the value of $100 \mathrm{mg} \mathrm{kg}^{-1}$ reported by Chino. ${ }^{[19]}$ At the lower $\mathrm{Zn}$ level in the solution, an abrupt drop of root dry matter was recorded already at $60.1 \mathrm{mg} \mathrm{kg}^{-1}$ of $\mathrm{Cd}$ in roots. $\mathrm{Cd}$ concentrations in root tissue were more than doubled during the last 22 days of experiment. At harvest III, Cd concentration of $100 \mathrm{mg} \mathrm{kg}^{-1}$ in roots of plants grown at the lower $\mathrm{Zn}$ treatment, was exceeded already at $\mathrm{pCd}^{2+}$ of 10.00 . Based on outcomes of this study, the toxic concentration of $\mathrm{Cd}$ in roots is estimated to be between 60 and $120 \mathrm{mg} \mathrm{kg}^{-1}$ and the corresponding free $\mathrm{Cd}$ activity $\left(\mathrm{pCd}^{2+}\right)$ associated with a toxicity effect is within a range of 10.25-9.75 depending on $\mathrm{Zn}$ level in the solution and the time period that plant roots were exposed to these concentrations. At harvests II and III, Cd toxicity threshold in shoots $\left(5 \mathrm{mg} \mathrm{kg}^{-1},{ }^{[19]}\right)$ was reached at the highest $\mathrm{Cd}$ level in the solution regardless of $\mathrm{Zn}$ treatment. $\mathrm{Zn}$ level in the nutrient solution did not affect $\mathrm{Cd}$ concentrations in rice shoots at the first two sampling dates but at the end of experiment (harvest III), Zn statistically significantly $(P<0.05)$ 

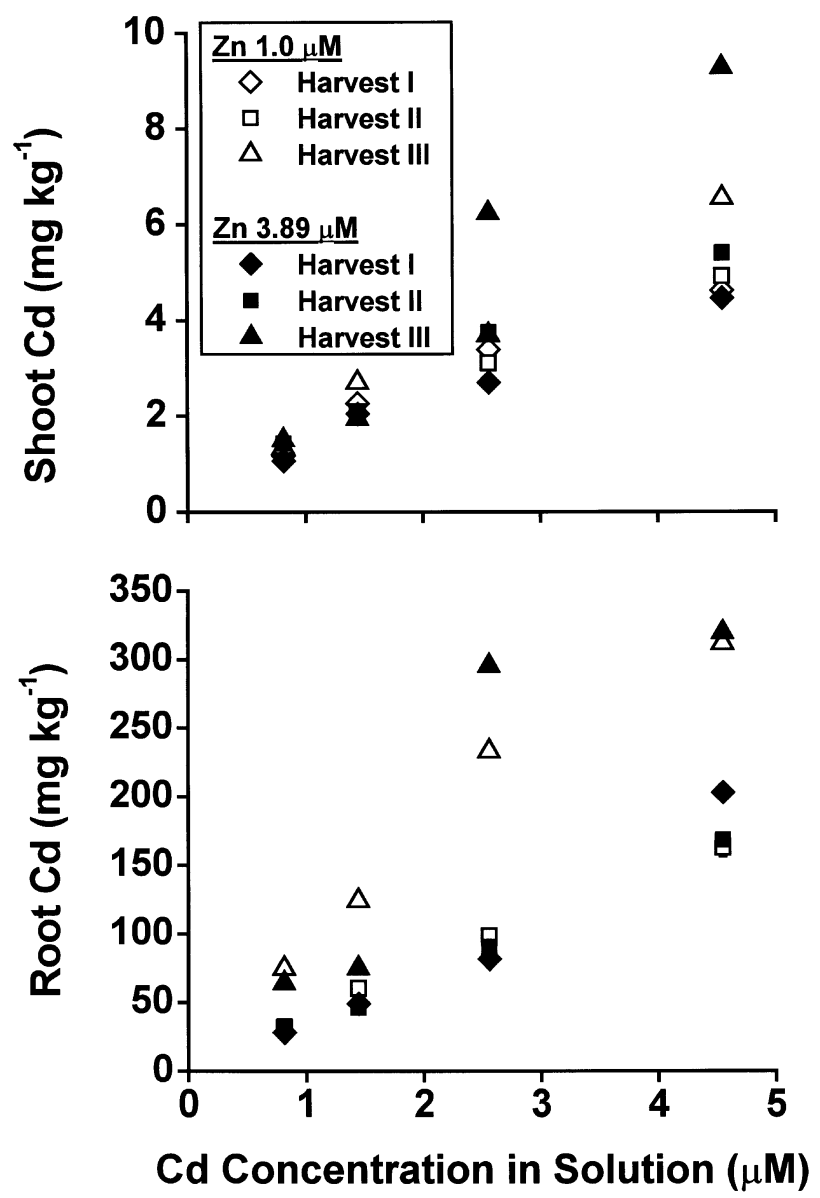

Figure 2. The effect of $\mathrm{Cd}$ and $\mathrm{Zn}$ concentrations in the growth solution and harvest date on the $\mathrm{Cd}$ concentrations in rice shoots and roots.

stimulated $\mathrm{Cd}$ translocation from roots to shoots at the two higher levels of $\mathrm{Cd}$ in solution.

\section{Cadmium Shoot-to-Root Ratios}

The ratio of the $\mathrm{Cd}$ concentration in plant tops to its concentrations in roots, the shoot-to-root ratio, is used to characterize element translocation from roots to shoots. When Cd level in solution was increased from 0.81 to $1.44 \mu \mathrm{M}$, 
shoot-to-root ratio increased (Fig. 3). Further increase of $\mathrm{Cd}$ in the nutrient solution was associated with decreased translocation of $\mathrm{Cd}$ from roots to shoots during the first 67 days of plant growth. At the end of experiment, the $\mathrm{Cd}$ translocation from roots to shoots was independent of $\mathrm{Cd}$ treatment.

\section{Other Elements}

Iron and $\mathrm{Mg}$ were the most consistently affected by the $\mathrm{Cd}$ treatments in the course of the experiment. Statistically significant decrease of $\mathrm{Mg}$ concentration in roots and shoots with increase of Cd level in solution was observed in harvests II and III. The highest $\mathrm{Cd}$ level in solution significantly decreased Ca concentrations in shoots at the early stage of growth (data not shown). Iron concentrations in the shoots were decreased at higher $\mathrm{Cd}$ concentrations in the solution, and in plant tissue, at all sampling dates, but the effect was not very pronounced (Fig. 4). A substantial decrease in shoot Fe concentrations, not related to $\mathrm{Cd}$ treatments, was observed at later phases of plant growth. At harvests II and III, plants were Fe deficient, regardless of $\mathrm{Cd}$ treatment, if $50 \mathrm{mg} \mathrm{Fe} \mathrm{kg}^{-1}$ of shoot dry matter is adopted as a sufficiency threshold. ${ }^{[21]}$ The low Fe status likely contributed to development of chlorosis in all plants, regardless of $\mathrm{Cd}$ treatment, at the later stages of growth. None of the other macro and micronutrients analyzed in the shoots, at any harvest date, was below sufficiency level or exceeded values typical for field grown rice plants (data not shown).

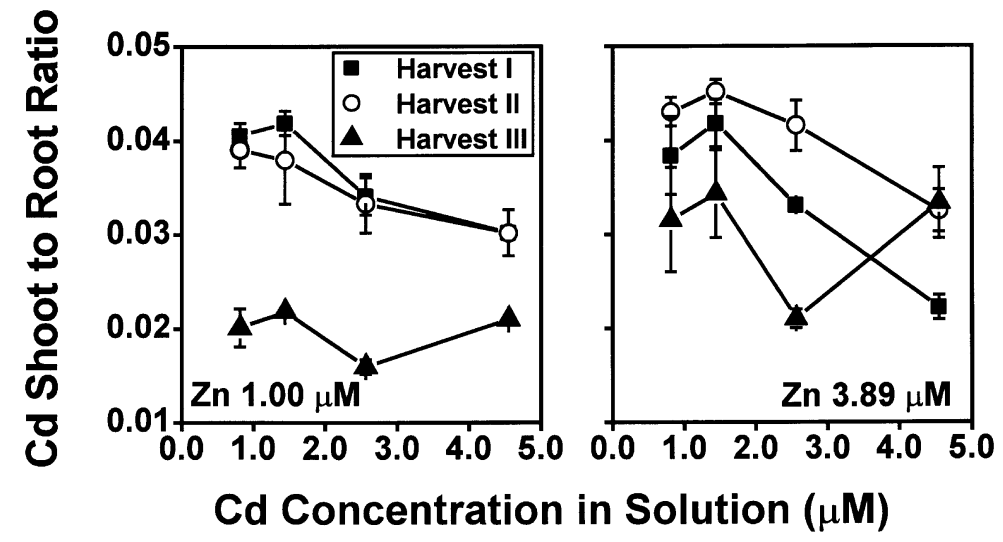

Figure 3. The ratios of $\mathrm{Cd}$ concentrations in shoots to $\mathrm{Cd}$ concentrations in roots (shootto-root ratios) as affected by a harvest date and $\mathrm{Cd}$ and $\mathrm{Zn}$ concentration in the solution; error bars show standard errors. 


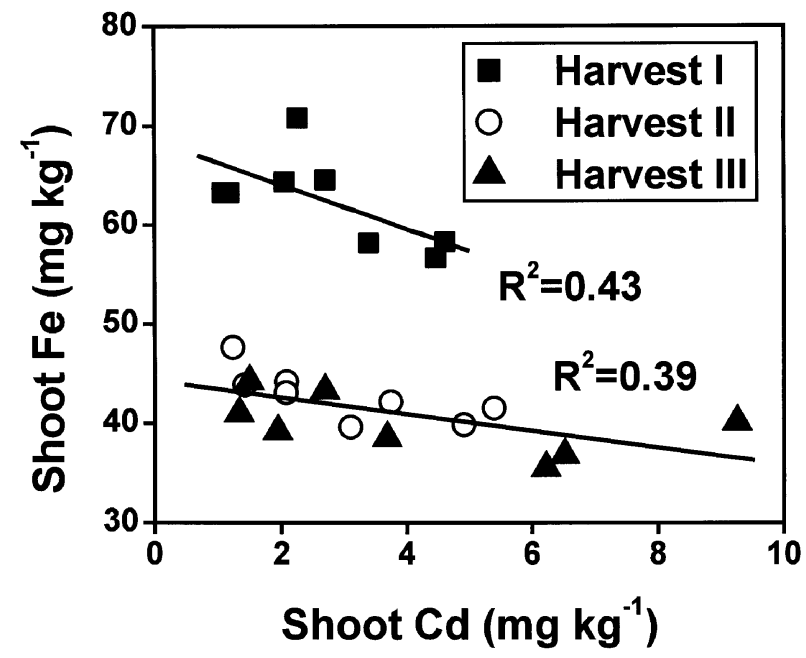

Figure 4. The relationship between $\mathrm{Cd}$ and $\mathrm{Fe}$ concentrations in rice shoots at different harvest dates.

\section{Symptoms}

The results of plant shoot rating performed four times during the experiment are presented in Fig. 5. The scores represent combined chlorosis and necrosis severity ratings using a scale from 0 (normal green plants) to 4 (severe chlorosis and necrosis). The lower scores corresponded with better plant performance. Repeated-measures analysis of variance revealed a highly significant effect of time $(P<0.001), \mathrm{Cd}(P<0.005)$, and $\mathrm{Zn}(P<0.05)$ levels in solution on the score values. At the early stage of growth, a very slight chlorosis was the only symptom developed by plants grown in the two lowest $\mathrm{Cd}$ treatments. The intensity of both symptoms progressed with time. A detrimental effect of the two highest $\mathrm{Cd}$ treatments was evident after 17 days of plant growth in nutrient solution; Cd toxicity was manifested by a leaf chlorosis. As plants accumulated higher amounts of $\mathrm{Cd}$ in shoots and roots in the course of the experiment, stronger chlorosis accompanied by leaf necrosis developed. At the two higher $\mathrm{Cd}$ treatments the higher $\mathrm{Zn}$ level in the nutrient solution clearly had a positive effect on plant performance, although it not only did not inhibit but even slightly stimulated $\mathrm{Cd}$ uptake by rice. At each $\mathrm{Cd}$ treatment, plants grown at the higher $\mathrm{Zn}$ solution level had less severe chlorosis and necrosis. Toxicity symptoms were not observed in the roots despite a substantial accumulation of $\mathrm{Cd}$. 

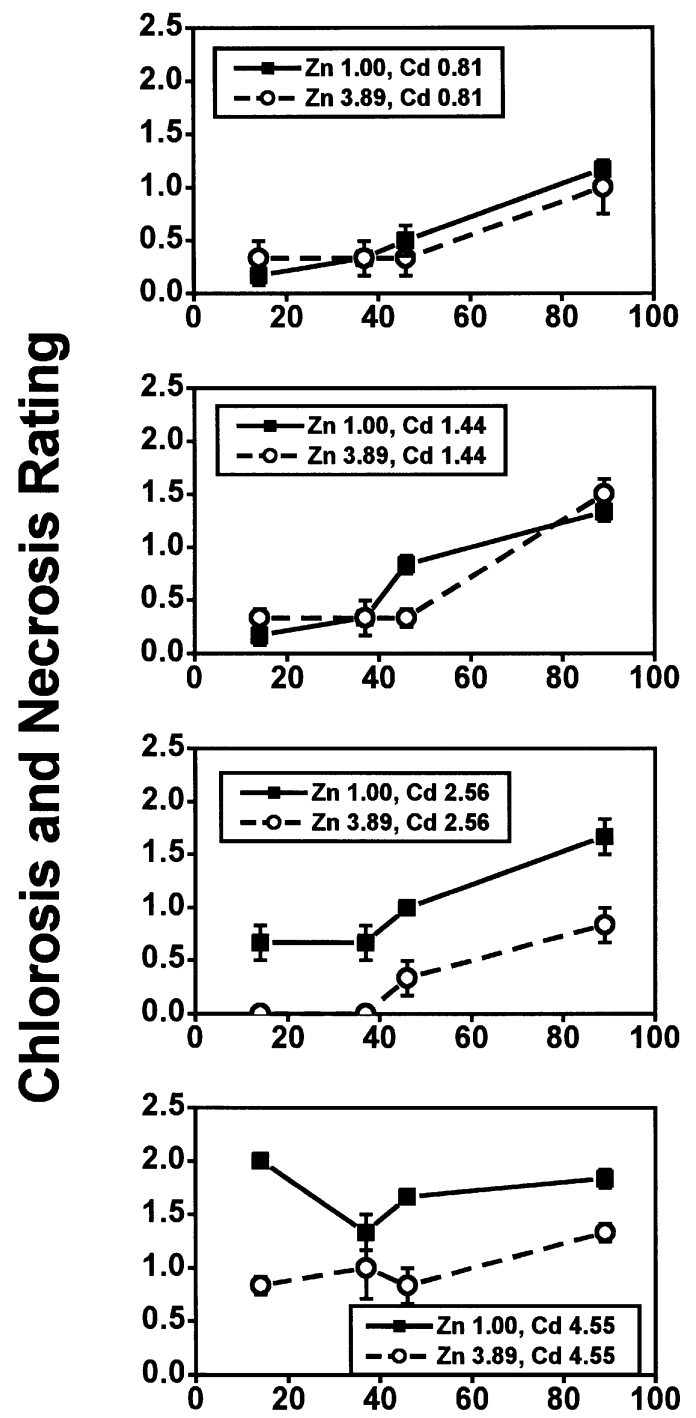

\section{Days of Growth}

Figure 5. Visual symptoms scores of plants grown at different $\mathrm{Zn}$ and $\mathrm{Cd}$ concentrations in the growth solution (scale from $0=$ Green to $4=$ severe chlorosis plus necrosis). Higher scores correspond with more intensive chlorosis and necrosis of the leaves; error bars show standard errors. 


\section{RESULTS OF EXPERIMENT II}

\section{Plant Growth and Grain Yield}

Both solutions enabled production of rice grain. Based on Experiment I, lower concentrations of $\mathrm{Cd}$ in solutions were used, and $\mathrm{Cd}$ treatments did not have any statistically significant effects on root and shoot biomass or grain yield. No symptoms of $\mathrm{Cd}$ toxicity were observed at any $\mathrm{Cd}$ treatment. In contrast, the composition of nutrient solution had a pronounced effect on plant growth and grain yield (Table 3). Plants grown in solution $G$ produced a larger number of tillers but not all tillers flowered, and not all those which flowered produced grain. All tillers of plants grown in solution $C$ produced grain. Tillers of plants in $G$ were longer than those of plants grown in solution $\mathrm{C}$ and their dry matter was twofold higher. The dry matter of the roots of plants grown in solution $\mathrm{G}$ was slightly lower, and roots were much shorter, than these of plants grown in solution $\mathrm{C}$. Yield of grain harvested from plants grown in solution $\mathrm{G}$ was higher than that harvested from plants grown in solution $\mathrm{C}$.

\section{Elemental Composition of Grain and Other Plant Parts}

At corresponding $\mathrm{Cd}$ levels in the growth medium, plants grown in solution $\mathrm{G}$ absorbed slightly more $\mathrm{Cd}$ than plants grown in solution $\mathrm{C}$ (Table 4); the greatest difference was observed in grain $\mathrm{Cd}$ (Fig. 6). The relationship between $\mathrm{Cd}$ concentrations in the nutrient solution and $\mathrm{Cd}$ levels in various plant parts was almost linear as shown for Cd concentrations in grain (Fig. 6). Separate linear regression lines were required for plants grown in solutions $\mathrm{G}$ and $\mathrm{C}$ indicating

Table 3. Rice Response to Nutrient Solutions

\begin{tabular}{|c|c|c|c|c|c|c|}
\hline \multirow{2}{*}{$\begin{array}{l}\text { Growth } \\
\text { Solution }\end{array}$} & \multirow{2}{*}{$\begin{array}{c}\text { Number } \\
\text { of Tillers/ } \\
\text { Plant }\end{array}$} & $\begin{array}{l}\text { The Tallest } \\
\text { Tiller } \\
\text { Length }\end{array}$ & $\begin{array}{c}\text { The Longest } \\
\text { Root } \\
\text { Length }\end{array}$ & $\begin{array}{l}\text { Shoot } \\
\text { Yield }\end{array}$ & $\begin{array}{l}\text { Root } \\
\text { Yield }\end{array}$ & $\begin{array}{l}\text { Grain } \\
\text { Yield }\end{array}$ \\
\hline & & \multicolumn{2}{|c|}{$\mathrm{cm}$} & \multicolumn{3}{|c|}{$\mathrm{g} /$ Plant } \\
\hline G & $20 \mathrm{a}^{\dagger}$ & $69.4 a$ & $47.4 \mathrm{a}$ & $53.7 \mathrm{a}$ & $4.70 \mathrm{a}$ & $23.0 \mathrm{a}$ \\
\hline $\mathrm{C}$ & $12 \mathrm{~b}$ & $59.9 b$ & $71.2 \mathrm{~b}$ & $24.4 \mathrm{~b}$ & $5.20 \mathrm{~b}$ & $17.5 \mathrm{~b}$ \\
\hline
\end{tabular}

${ }^{\dagger}$ Means within a column followed by the same letter are not significantly different according to the $t$-test $(P<0.05)$. 


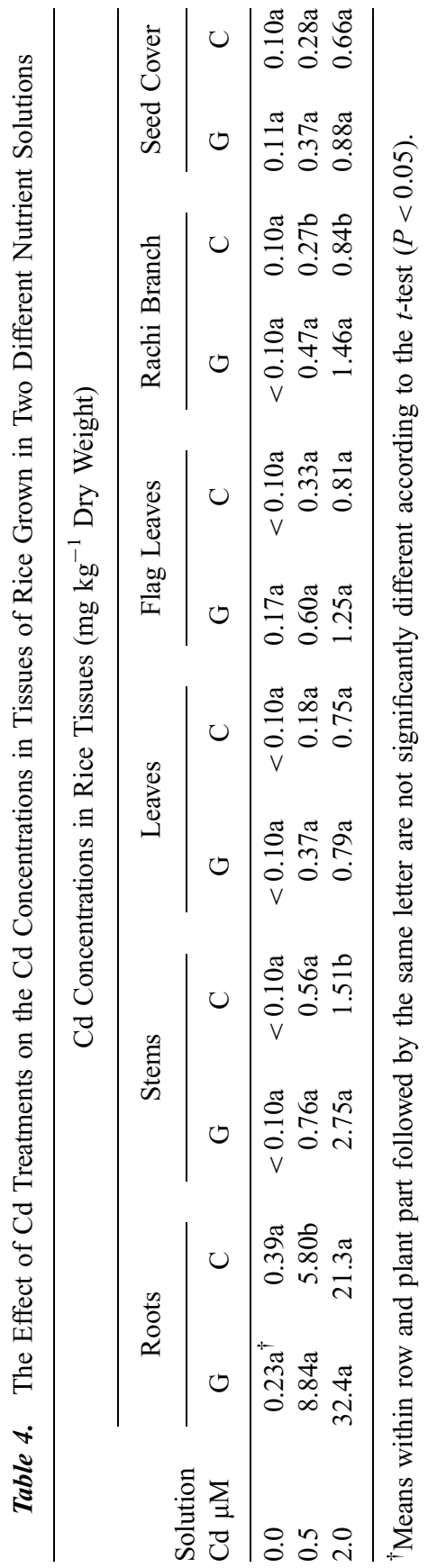




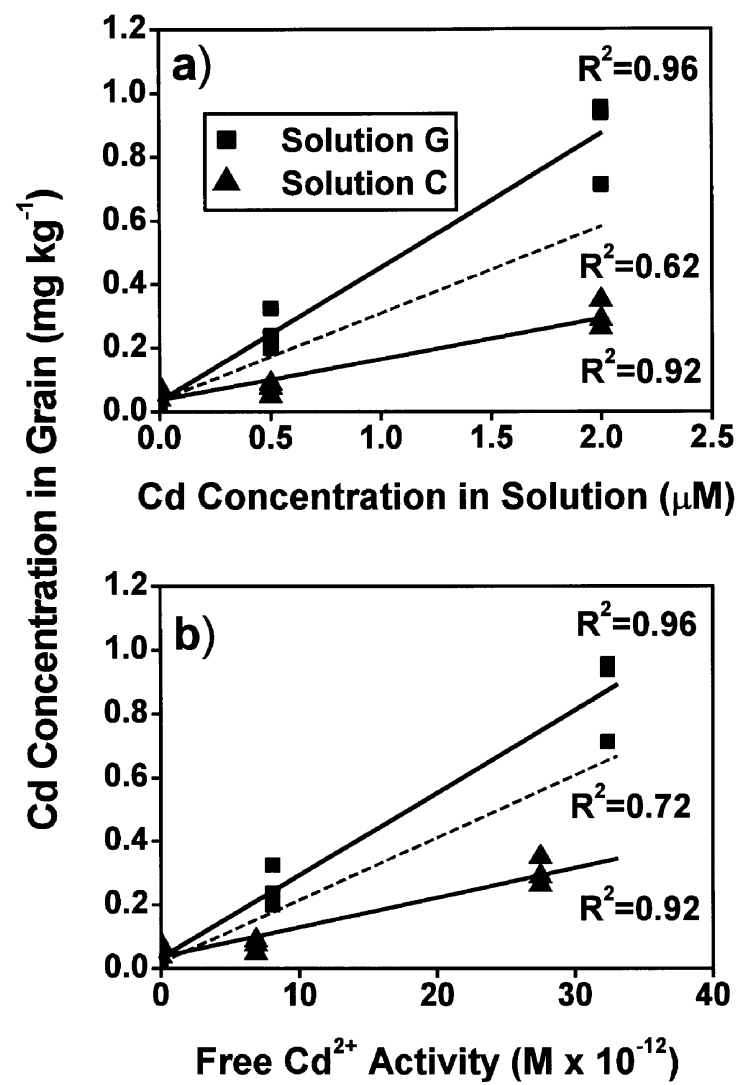

Figure 6. The effect of a) Cd concentration in the growth solution and b) free $\mathrm{Cd}^{2+}$ activity in the growth solution on $\mathrm{Cd}$ level in the rice grain. Solid lines are the respective linear functions fitted to solution $\mathrm{G}$ and solution $\mathrm{C}$ data treated as separate data sets. The dotted lines are for a linear function fitted to the pooled solution $\mathrm{G}$ and solution C data.

that factors other than $\mathrm{Cd}$ concentrations in the nutrient solutions were also involved. At the same levels of total $\mathrm{Cd}$ applied, $\mathrm{Cd}^{2+}$ activities in the solution $\mathrm{C}$ were slightly lower than in solution G. Replacing concentrations of $\mathrm{Cd}$ in the solutions by the free $\mathrm{Cd}^{2+}$ activity gave closer agreement in $\mathrm{Cd}$ concentrations in grain (Fig. 6) and other parts (data not shown) of plants grown in solutions $\mathrm{G}$ and $\mathrm{C}$.

Although composition of the nutrient solutions induced considerable differences in some micro- and macronutrient concentrations in the roots and 
Table 5. Micronutrient Concentrations in Various Parts of Rice Plants

\begin{tabular}{|c|c|c|c|c|c|c|}
\hline \multirow[b]{2}{*}{ Plant Part } & \multirow[b]{2}{*}{ Solution } & \multicolumn{5}{|c|}{ Micronutrient Concentrations (mg kg ${ }^{-1}$ Dry Weight) } \\
\hline & & $\mathrm{Cu}$ & $\mathrm{Fe}$ & $\mathrm{Zn}$ & $\mathrm{Mn}$ & Mo \\
\hline \multirow[t]{2}{*}{ Grain } & G & $7.08 \mathrm{a}^{\dagger}$ & $14.3 \mathrm{a}$ & $42.0 \mathrm{a}$ & $5.45 \mathrm{a}$ & $1.19 \mathrm{a}$ \\
\hline & $\mathrm{C}$ & $6.35 b$ & $10.5 \mathrm{a}$ & $38.6 b$ & $10.9 b$ & $1.44 \mathrm{~b}$ \\
\hline \multirow[t]{2}{*}{ Seed Cover } & $\mathrm{G}$ & $7.37 \mathrm{a}$ & $16.3 \mathrm{a}$ & $15.5 \mathrm{a}$ & $23.6 \mathrm{a}$ & $1.74 \mathrm{a}$ \\
\hline & $\mathrm{C}$ & $7.21 \mathrm{a}$ & $18.8 \mathrm{a}$ & $16.6 \mathrm{a}$ & $149.0 \mathrm{~b}$ & $2.61 \mathrm{~b}$ \\
\hline \multirow[t]{2}{*}{ Rachi Branch } & G & $9.62 \mathrm{a}$ & $30.7 \mathrm{a}$ & $51.5 \mathrm{a}$ & $30.4 \mathrm{a}$ & $1.19 \mathrm{a}$ \\
\hline & $\mathrm{C}$ & $8.84 \mathrm{a}$ & $32.7 \mathrm{a}$ & $46.9 b$ & $114.0 \mathrm{~b}$ & $3.01 \mathrm{~b}$ \\
\hline \multirow[t]{2}{*}{ Flag Leaves } & $\mathrm{G}$ & $12.8 \mathrm{a}$ & $67.1 \mathrm{a}$ & $28.9 \mathrm{a}$ & $30.1 \mathrm{a}$ & $3.64 \mathrm{a}$ \\
\hline & $\mathrm{C}$ & $14.0 \mathrm{~b}$ & $79.4 b$ & $20.7 b$ & $333.0 \mathrm{~b}$ & $5.88 \mathrm{~b}$ \\
\hline \multirow[t]{2}{*}{ Leaves } & G & $7.71 \mathrm{a}$ & $90.9 \mathrm{a}$ & $23.8 \mathrm{a}$ & $41.1 \mathrm{a}$ & $3.91 \mathrm{a}$ \\
\hline & $\mathrm{C}$ & $11.6 \mathrm{~b}$ & $90.1 \mathrm{a}$ & $23.0 \mathrm{a}$ & $409.0 \mathrm{~b}$ & $4.18 \mathrm{a}$ \\
\hline \multirow[t]{2}{*}{ Stem } & $\mathrm{G}$ & $7.42 \mathrm{a}$ & $22.2 \mathrm{a}$ & $48.7 \mathrm{a}$ & $9.77 \mathrm{a}$ & $2.09 \mathrm{a}$ \\
\hline & $\mathrm{C}$ & $9.50 \mathrm{~b}$ & $57.9 \mathrm{~b}$ & $73.4 \mathrm{~b}$ & $48.5 b$ & $3.03 b$ \\
\hline \multirow[t]{2}{*}{ Roots } & G & $87.8 \mathrm{a}$ & $297 \mathrm{a}$ & $23.8 \mathrm{a}$ & $4.50 \mathrm{a}$ & $0.47 \mathrm{a}$ \\
\hline & $\mathrm{C}$ & $110.0 \mathrm{~b}$ & $332 b$ & $22.6 \mathrm{a}$ & $8.80 \mathrm{~b}$ & $1.86 \mathrm{~b}$ \\
\hline
\end{tabular}

${ }^{\dagger}$ Means within a column and plant part followed by the same letter are not significantly different according to the $t$-test $(P<0.05)$.

shoots of plants, there was little variation in the grain composition (Tables 5 and 6). Mn concentration of plants was the most striking example. Due to a higher concentration of this element in solution $\mathrm{C}$, plants grown in this solution accumulated 10 times more $\mathrm{Mn}$ in their leaves and flag leaves than plants grown in solution G. Manganese concentration in the seed covers of rice grown in solution $\mathrm{C}$ was 6 times higher, but $\mathrm{Mn}$ concentration in the brown rice grain from solution $\mathrm{C}$ was only twofold higher than in the grain grown in solution G.

The ratios of trace metal concentrations in shoots to those in roots (shootto-root) ratios at harvest, are presented in Table 7. The shoot-to-root ratio for $\mathrm{Cd}$ was the lowest among all elements analyzed. Copper and Fe were also accumulated primarily in the roots with very little translocation from roots to shoots. In contrast, $\mathrm{Zn}$ and $\mathrm{Mn}$ were concentrated in shoots, although for $\mathrm{Zn}$, this effect was not consistent (see Experiment I, harvest II). The order of the shoot-toroot ratios for cationic microelements obtained in our studies with all solutions was as follows: $\mathrm{Mn}>\mathrm{Zn}>\mathrm{Fe} \geq \mathrm{Cu}>\mathrm{Cd}$. 
Table 6. Macronutrient Concentrations in Various Parts of Rice Plants

\begin{tabular}{lccccc}
\hline & & \multicolumn{4}{c}{$\begin{array}{c}\text { Macronutrient Concentrations } \\
\left(\mathrm{g} \mathrm{kg}^{-1} \text { Dry Weight }\right)\end{array}$} \\
\cline { 3 - 6 } Plant Part & Solution & $\mathrm{P}$ & $\mathrm{Mg}$ & $\mathrm{Ca}$ & $\mathrm{K}$ \\
\hline Grain & $\mathrm{G}$ & $2.95 \mathrm{a}^{\dagger}$ & $0.99 \mathrm{a}$ & $0.068 \mathrm{a}$ & $1.89 \mathrm{a}$ \\
& $\mathrm{C}$ & $2.67 \mathrm{a}$ & $0.90 \mathrm{a}$ & $0.064 \mathrm{a}$ & $1.40 \mathrm{~b}$ \\
Seed Cover & $\mathrm{G}$ & $1.20 \mathrm{a}$ & $1.10 \mathrm{a}$ & $1.55 \mathrm{a}$ & $16.4 \mathrm{a}$ \\
\multirow{3}{*}{ Rachi Branch } & $\mathrm{C}$ & $1.39 \mathrm{~b}$ & $1.43 \mathrm{~b}$ & $2.05 \mathrm{~b}$ & $13.8 \mathrm{~b}$ \\
& $\mathrm{G}$ & $1.78 \mathrm{a}$ & $2.30 \mathrm{a}$ & $1.76 \mathrm{a}$ & $10.5 \mathrm{a}$ \\
Flag Leaves & $\mathrm{C}$ & $2.25 \mathrm{~b}$ & $3.21 \mathrm{~b}$ & $1.97 \mathrm{~b}$ & $9.14 \mathrm{~b}$ \\
& $\mathrm{G}$ & $2.95 \mathrm{a}$ & $4.56 \mathrm{a}$ & $5.65 \mathrm{a}$ & $17.2 \mathrm{a}$ \\
Leaves & $\mathrm{C}$ & $3.05 \mathrm{a}$ & $6.91 \mathrm{~b}$ & $8.63 \mathrm{~b}$ & $11.1 \mathrm{~b}$ \\
& $\mathrm{G}$ & $2.98 \mathrm{a}$ & $6.85 \mathrm{a}$ & $6.26 \mathrm{a}$ & $19.6 \mathrm{a}$ \\
Stem & $\mathrm{C}$ & $2.95 \mathrm{a}$ & $9.30 \mathrm{~b}$ & $7.09 \mathrm{~b}$ & $10.4 \mathrm{~b}$ \\
\multirow{2}{*}{ Roots } & $\mathrm{G}$ & $5.11 \mathrm{a}$ & $2.17 \mathrm{a}$ & $0.96 \mathrm{a}$ & $37.5 \mathrm{a}$ \\
& $\mathrm{C}$ & $4.60 \mathrm{~b}$ & $3.85 \mathrm{~b}$ & $1.09 \mathrm{~b}$ & $27.8 \mathrm{~b}$ \\
& $\mathrm{G}$ & $2.20 \mathrm{a}$ & $0.44 \mathrm{a}$ & $1.31 \mathrm{a}$ & $11.0 \mathrm{a}$ \\
& $\mathrm{C}$ & $1.54 \mathrm{~b}$ & $0.86 \mathrm{~b}$ & $1.05 \mathrm{~b}$ & $6.78 \mathrm{~b}$ \\
\hline
\end{tabular}

${ }^{\dagger}$ Means within a column and plant part followed by the same letter are not significantly different according to the $t$-test $(P<0.05)$.

Table 7. Elemental Shoot-to-Root Ratios

\begin{tabular}{lccccc}
\hline Experiment & $\mathrm{Mn}$ & $\mathrm{Zn}$ & $\mathrm{Fe}$ & $\mathrm{Cu}$ & $\mathrm{Cd}$ \\
\hline $\begin{array}{l}\text { Experiment I - } \\
\quad \text { Harvest I }\end{array}$ & $\mathrm{nd}^{\dagger}$ & $2.41-1.49$ & 0.134 & 0.131 & 0.035 \\
$\begin{array}{c}\text { Experiment I - } \\
\quad \text { Harvest II }\end{array}$ & 4.67 & $0.90-0.64$ & 0.131 & 0.105 & 0.038 \\
$\begin{array}{c}\text { Experiment I - } \\
\quad \text { Harvest III }\end{array}$ & 8.71 & $1.35-1.21$ & 0.130 & 0.145 & 0.025 \\
$\begin{array}{c}\text { Experiment II - } \\
\quad \text { Solution G }\end{array}$ & 5.37 & 1.54 & 0.185 & 0.091 & $0.072-0.057$ \\
$\begin{array}{c}\text { Experiment II - } \\
\text { Solution C }\end{array}$ & 26.7 & 2.26 & 0.222 & 0.097 & $0.066-0.053$ \\
\hline
\end{tabular}

${ }^{\dagger}$ Not determined.

tHeads were excluded from calculations of shoot-to-root ratios. 


\section{DISCUSSION}

\section{Shoot-to-Root Ratios for Elements}

The shoot-to-root ratio for $\mathrm{Cd}$ was the lowest among all elements analyzed and corresponded fairly well with the values reported by Chino and $\mathrm{Baba}^{[22]}$ and Honma and Hirata ${ }^{[23]}$ for rice grown in traditional nutrient solutions. The order of shoot-to-root ratios for cationic trace metals obtained in our experiment $\mathrm{Mn}>\mathrm{Zn}>\mathrm{Cu}>\mathrm{Cd}$ closely resembled that obtained by limura et al. ${ }^{[24]}$ and Chino and Baba. ${ }^{[22]}$ As suggested by Chino, ${ }^{[19]}$ this order is related to a stability of metal organic chelates. Metals which form stable complexes with organic and amino acids and proteins are retained in the roots. The shoot-to-root ratios for $\mathrm{Mn}, \mathrm{Zn}$, and $\mathrm{Cu}$ obtained in our study are of the same magnitude as values reported for rice by Chino and $\mathrm{Baba}^{[22]}$ and Obata and Umebayashi. ${ }^{[25]}$ The limited transfer of $\mathrm{Cd}$ and $\mathrm{Cu}$ from roots to shoots is characteristic of many plant species, ${ }^{[25,26]}$ but some species tend to accumulate more $\mathrm{Cd}$ in shoots than in roots. $^{[27]}$ Zinc was found to be preferentially accumulated in tops of barley (Hordeum vulgare L.), ${ }^{[28]}$ which supports Chino's model, but there are also contrary observations. ${ }^{[26,29]}$ Also partitioning of Mn between roots and shoots seems to be a specific feature of plant species. ${ }^{[25]}$ These observations suggest a diversity of processes governing translocation of trace elements within plants.

Advantages of chelator buffered nutrient solutions make them a tool of choice when a stabilizing of free metal activity in hydroponic solution is of interest or severe deficiency of a micronutrient is to be imposed. The selection of a chelator, or a combination of chelators, depends on the purpose of the study and plant species investigated. There is no one universal chelator that can be used in every situation and for every plant species. Yang et al. ${ }^{[30]}$ demonstrated that HEDTA can be recommended for the hydroponic studies with rice while DTPA, for many reasons, was not a suitable chelator for buffering free metal activities.In this context, it is worth noting good agreement of the shoot-to-root elemental ratios obtained in both our experiments with values reported for rice grown in conventional nutrient solutions. Furthermore, macro- and microelement concentrations in plant shoots, except for slightly deficient Fe in Experiment I, were typical of rice plants grown under field conditions. This, along with a good grain yield obtained with both $\mathrm{G}$ and $\mathrm{C}$ solutions shows the suitability of chelators selected for buffering the activity of trace metal cations in this hydroponic studies with rice.

\section{Zinc-Cadmium Interaction}

The higher level of $\mathrm{Zn}$ in the solution, and subsequently in plant tissue, ameliorated $\mathrm{Cd}$ induced chlorosis of rice shoots despite promoting $\mathrm{Cd}$ 
translocation from roots to shoots in the later phase of growth. The most commonly observed effect is an antagonistic interaction between $\mathrm{Cd}$ and

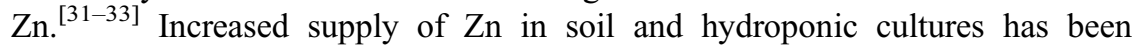
reported to decrease Cd uptake by a variety of plant species including rice. ${ }^{[34]}$ The effect is especially pronounced when $\mathrm{Zn}$ is raised from a deficiency to sufficiency level (rice, ${ }^{[23]}$ lettuce ${ }^{[32]}$ ). Other studies demonstrated that the nature of the interaction between these two elements is more complex. Application of $\mathrm{Zn}$ to a soil of a low adsorptive capacity, in some cases, promoted Cd uptake by rice because $\mathrm{Cd}$ was replaced by $\mathrm{Zn}$ in the soil adsorptive complex and $\mathrm{Cd}$ concentration in soil solution increased. ${ }^{[35]}$ Growing plants in nutrient solutions allows for elimination of complications associated with soil solid phases, but hydroponic studies have also yielded conflicting results regarding interactions of $\mathrm{Zn}$ with $\mathrm{Cd}$. Both antagonistic and synergistic interactions between $\mathrm{Zn}$ and $\mathrm{Cd}$ were observed by McKenna et al. ${ }^{[29]}$ in their hydroponic experiment with lettuce and spinach. The mode of interaction was dependent on the relative concentration of elements in nutrient solution and did not exhibit any definite trends. Girling and Peterson ${ }^{[34]}$ noticed that at equimolar concentrations of $\mathrm{Zn}$ and $\mathrm{Cd}$ in a nutrient solution $\mathrm{Zn}$ stimulated uptake of $\mathrm{Cd}$ by corn but when $\mathrm{Zn}: \mathrm{Cd}$ ratio in solution was increased, the antagonistic effect of $\mathrm{Zn}$ on $\mathrm{Cd}$ uptake became evident. Honma and Hirata ${ }^{[23]}$ and Green et al. ${ }^{[36]}$ observed similar effects in hydroponically grown rice plants and concluded that the synergistic or antagonistic effect between $\mathrm{Zn}$ and $\mathrm{Cd}$ depended on the $\mathrm{Cd}: \mathrm{Zn}$ ratio and the absolute level of $\mathrm{Cd}$ in nutrient solution.

\section{Zinc Uptake}

In Experiment I, Zn concentrations in roots and shoots, at harvest I, were fairly close to values recorded by Green et al. ${ }^{[36]}$ in rice plants of similar age, at $\mathrm{pZn}^{2+}$ activities 6.6 and 6.1, similar to these used in our study. The $\mathrm{pZn}^{2+}$ causing $20 \%$ decrease of the roots and shoot yield estimated from their study was 5.9. In our experiment, a depression of shoot and root yield by 33 and $41 \%$, respectively, occurred at $\mathrm{pZn}^{2+}$ 6.0. It appears that the free $\mathrm{Zn}^{2+}$ activity toxic to young rice plants grown in the EGTA buffered nutrient solution is about $\mathrm{pZn}^{2+}=6.0$.

The decrease of root and shoot $\mathrm{Zn}$ concentrations observed in our study at harvest II could be to some extent attributed to a depletion of the solution $\mathrm{Zn}$ caused by a vigorous growth of plants. This explanation is probably sufficient for plants grown at $1.0 \mu \mathrm{M} \mathrm{Zn}$ in the solution. A mass balance for $3.89 \mu \mathrm{M} \mathrm{Zn}$ solution indicated that the depletion of $\mathrm{Zn}$ in the growth medium probably was not large enough to cause a drop of shoot $\mathrm{Zn}$ concentration from about $100 \mathrm{mg} \mathrm{kg}^{-1}$, at harvest I, to about $30-35 \mathrm{mg} \mathrm{kg}^{-1}$ at harvests II and III. It seems 
possible that critical concentrations, or activities, of $\mathrm{Zn}$ in the solution may vary depending on the age of plants. Testing this hypothesis would require a thorough study with a frequent changes of the growth solution to minimize depletion of $\mathrm{Zn}$ in the growth medium.

\section{Cadmium Uptake}

The introduction of chemical equilibrium computer models enabled calculation of metal speciation in hydroponic growth media and soil solution. Since then, increasing evidence has indicated that plant uptake of many metallic cations is related to free cation concentration or activity rather than a total metal concentration in growth media. ${ }^{[16]}$ There are also contrary observations indicating that total metal concentration in a growing medium can not be ignored. ${ }^{[28]}$ Substituting $\mathrm{Cd}$ concentrations in the growth solutions (Experiment II) by free $\mathrm{Cd}^{2+}$ activities noticeably reduced variation of $\mathrm{Cd}$ in grain (Fig. 6) and, to a lesser extent, in roots and other plant parts, which may be seen as supporting the concept that $\mathrm{Cd}$ uptake and transport within rice plant is an active process. Fujimoto and Uchida ${ }^{[37]}$ reached the same conclusion by comparing the increase in $\mathrm{Cd}$ concentration of the whole rice plants grown in a hydroponic culture with an expected $\mathrm{Cd}$ concentration based on the water transpiration coefficient. The decrease of shoot-to-root ratios with increasing $\mathrm{Cd}$ concentrations in the solution (Experiment I, harvests I and II), observed also by Chino and $\mathrm{Baba},{ }^{[22]}$ also supports the thesis that $\mathrm{Cd}$ transport from roots to shoots is actively regulated by the rice plants. At the end of Experiment I, when Cd level in roots approached a toxicity threshold even at the lowest $\mathrm{Cd}$ treatment, the $\mathrm{Cd}$ shoot-to-root ratio became independent of the $\mathrm{Cd}$ level in the growth medium which suggests that $\mathrm{Cd}$ translocation from roots to shoots is dependent on $\mathrm{Cd}$ concentration in the roots rather than metal concentration in the solution. There are evidences that $\mathrm{Cd}$ is transported to the rice shoots in form of organic complexes when it is present at low concentrations in the root zone, but at higher concentrations metal is retained in the roots as inorganic compounds. ${ }^{[2]} \mathrm{A}$ presence of electron-dense Cd deposits in the roots of corn (Zea mays L.) and Agrostis giganta $^{[38]}$ showed that most species accumulate toxic metals in their roots.

\section{Composition of Rice Grain}

The difference between $\mathrm{Cd}$ concentrations in the grain and other parts of plants grown in solutions $\mathrm{G}$ and $\mathrm{C}$ at the same $\mathrm{Cd}$ concentration, or the same free $\mathrm{Cd}^{2+}$ activity, indicated that some other factor(s) modified $\mathrm{Cd}$ translocation to the 
shoots and grain. Composition of the growth medium likely was the key factor modifying $\mathrm{Cd}$ uptake and translocation to the grain. Because solutions $\mathrm{G}$ and $\mathrm{C}$ differed in the concentrations of all cations and anions, this effect can not be attributed to any specific component. Cd treatment was initiated, at the same date for both solutions, after 76 days of plant growth. At this time, most plants in solution $\mathrm{C}$ had entered the flowering phase while plants in solution $\mathrm{G}$ had only begun to form flag leaves. Initiation of the Cd treatments at slightly different stages of the plant growth could have also affected $\mathrm{Cd}$ translocation to the grain. ${ }^{[39]}$ The duration of $\mathrm{Cd}$ treatments was longer for plants grown in solution $\mathrm{G}$ because grain was ripe in solution $\mathrm{C} 8$ days earlier. This factor was probably of minor importance because $\mathrm{Cd}$ translocation to grain is very limited in the late phase of grain ripening. ${ }^{[39]}$

There is a considerable disagreement on what elemental concentrations are typical for brown rice. According to Japanese studies, ${ }^{[24]} 30-50 \mathrm{mg} \mathrm{Zn} \mathrm{kg}^{-1}$ is considered a normal concentration for brown rice. Later studies ${ }^{[40]}$ revealed that $\mathrm{Zn}$ level of $28.5-38.5 \mathrm{mg} \mathrm{kg}^{-1}$ represents a maximum concentrations found in the brown rice from China, Indonesia, and Japan while average values for these countries were within the range of $21.5-23.4 \mathrm{mg} \mathrm{kg}^{-1}$. About $20 \mathrm{mg} \mathrm{Zn} \mathrm{kg}^{-1}$ was a maximum level for brown rice grown in the U.S. ${ }^{[41]}$ while $13.5 \mathrm{mg} \mathrm{kg}^{-1}$ was the mean value for U.S. brown rice, which agrees well with the mean value of $16.4 \mathrm{mg} \mathrm{kg}^{-1}$ obtained by Masironi et al. ${ }^{[42]}$ who analyzed samples of unpolished rice grain from various countries of the world. Therefore, $\mathrm{Zn}$ concentrations in the grain obtained in our study should be considered somewhat high. Copper and $\mathrm{Fe}$ levels in the grain obtained in our experiment were comparable to the maximum values reported for the brown rice from various countries. ${ }^{[1-43]}$ Manganese level in the grain grown in solution $G$ was close to the minimum while that of grain grown in solution $\mathrm{C}$ was close to the mean value reported for U.S. brown rice. ${ }^{[41]}$ Concentrations of the major elements $\mathrm{Ca}, \mathrm{Mg}, \mathrm{K}$, and $\mathrm{P}$ in grains grown in both solutions were close to values reported by Zhang et al. ${ }^{[7]}$ for a single case study in Japan. When compared with U.S. grown brown rice, they are close to maximum values. $^{[41]}$

A number of studies demonstrated that $\mathrm{Cd}$ retention in animals was greatly increased when animal diets were deficient in $\mathrm{Zn}, \mathrm{Fe}$, and/or $\mathrm{Ca},{ }^{[2,10]}$ and opposite, diets enriched in $\mathrm{Zn}$ significantly reduced $\mathrm{Cd}$ accumulation in animals. ${ }^{[9]}$ Genetic engineering offers a promising tool for increasing $\mathrm{Fe}$ bioavailability of rice grain. ${ }^{[44]}$ Higher concentrations of $\mathrm{Zn}, \mathrm{Fe}$, and $\mathrm{Ca}$ in comparison to most commercially available brown rice grain is of special importance for a feeding study because it could confound the bioavailability of the rice Cd. Solution to this problem would be a modification of the growth solution composition and the repetition of the experiment until the grain with a desired concentration of not only $\mathrm{Cd}$, but also $\mathrm{Zn}, \mathrm{Ca}$, and $\mathrm{Fe}$ is obtained. 


\section{ACKNOWLEDGMENTS}

We gratefully acknowledge the advice offered by Drs. Mitsuo Chino and Michael Grusak regarding their individual successful culture of growing rice to mature grain in growth chambers, and the preliminary results of the initial studies on growing rice using chelator-buffered nutrient solutions by Dr. Carrie E. Green; Dr. Green also kindly maintained all instruments and growth chambers needed for these studies; Dr. Tony Marchetti, USDA-ARS, Beaumont, TX, for providing certified seed of 'Jefferson' rice for these experiments. During this project, Dr. U. Kukier was a visiting scientist from the Institute of Soil Science and Plant Cultivation, Pulawy, Poland, supported by a grant from USDA-Foreign Agricultural Service to Dr. Tomasz I. Stuczynski in cooperative studies of soil $\mathrm{Cd}, \mathrm{Zn}$, and $\mathrm{Pb}$ remediation. Dr. Kukier is presently Research Scientist with the Department of Crop and Soil Environmental Sciences, Virginia Polytechnic Institute and State University, Blacksburg, VA.

\section{REFERENCES}

1. Tsuchiya, K. (Ed.) Cadmium Studies in Japan: A Review; Elsevier/NorthHolland Biomedical Press: New York, 1978; 376 pp.

2. Fox, M.R.S.; Tao, S.-H.; Stone, C.L.; Fry, B.E., Jr. Effects of Zinc, Iron, and Copper Deficiencies on Cadmium in Tissues of Japanese Quail. Environ. Health Perspect. 1984, 54, 57-65.

3. McKenna, I.M.; Chaney, R.L.; Tao, S.; Leach, R.M., Jr.; Williams, F.M. Interactions of Plant Zinc and Plant Species on the Bioavailability of Plant Cadmium to Japanese Quail Fed Lettuce and Spinach. Environ. Res. 1992, 57, 73-87.

4. Sakurai, H. Epidemiological Studies. In Cadmium Studies in Japan: A Review; Tsuchiya, K., Ed.; Elsevier/North-Holland Biomedical Press: Amsterdam, The Netherlands, 1978; 133-267.

5. Strehlow, C.D.; Barltrop, D. The Shipham Report: An Investigation into Cadmium Concentration and Its Implications for Human Health. 6. Health Studies. Sci. Total Environ. 1988, 75, 101-133.

6. Wolnik, K.A.; Fricke, F.L.; Capar, S.G.; Braude, G.L.; Meyer, M.W.; Satzger, R.D.; Kuennen, R.W. Elements in Major Raw Agricultural Crops in the United States. 2. Other Elements in Lettuce, Peanuts, Potatoes, Soybeans, Sweet Corn, and Wheat. J. Agric. Food Chem. 1983, 31, 1244-1249.

7. Zhang, Z.W.; Moon, C.S.; Watanabe, T.; Shimbo, S.; Ikeda, M. Contents of Pollutant and Nutrient Elements in Rice and Wheat Grown on the Neighboring Fields. Biol. Trace Element Res. 1997, 57, 39-50. 
8. Berglund, M.; Åkesson, A.; Nermell, B.; Vahter, M. Intestinal Absorption of Dietary Cadmium in Women Depends on Body Iron Stores and Fiber Intake. Environ. Health Perspect. 1994, 102, 1058-1066.

9. Stuczynski, T.; Pistelok, F.; Siebielec, G.; Kukla, H.; Daniels, W.; Chaney, R.; Pantuck, K. Biological Aspects of Metal Waste Reclamation with Sewage Sludge in Poland. In Mining, Forest and Land Restoration: The Successful Use of Residuals/Biosolids/Organic Matter for Reclamation Activities, Proceedings of Symposium, Denver, CO, July 17-20, 2000; Rocky Mountain Water Environment Association: Denver, CO, 2000; Chap. 5, 12 pp.

10. Reeves, P.G.; Chaney, R.L. Mineral Status of Female Rats Affects the Absorption and Organ Distribution of Dietary Cadmium Derived from Edible Sunflower Kernels (Helianthus annuus L.). Environ. Res., Section A, 2001, 85, 215-225.

11. Fox, M.R.S. Nutritional Factors that May Influence Bioavailability of Cadmium. J. Environ. Qual. 1988, 17, 175-180.

12. Chaney, R.L.; Ryan, J.A.; Li, Y.M.; Brown, S.L. Soil Cadmium as a Threat to Human Health. In Cadmium in Soils and Plants; McLaughlin, M.J., Singh, B.R., Eds.; Kluwer Academic Publishers: Dordrecht, Netherlands, 1999; 219-256.

13. Welch, R.M.; House, W.A.; Van Campen, D.R. Availability of Cadmium from Lettuce Leaves and Cadmium Sulfate to Rats. Nutr. Rept. Intern. 1978, 17, 35-42.

14. Chino, M. Uptake-Transport of Toxic Metals in Rice Plants. In Heavy Metals Pollution in Soils of Japan; Kitagishi, K., Yamane, I., Eds.; Japan Scientific Societies Press: Tokyo, 1981; 81-94.

15. Kitagishi, K.; Obata, H. Accumulation of Heavy Metals in Rice Grains. In Heavy Metal Pollution in Soils of Japan; Kitagishi, K., Yamane, E., Eds.; Japan Scientific Societies Press: Tokyo, 1981; 95-104.

16. Parker, D.R.; Chaney, R.L.; Norvell, W.A. Chemical Equilibrium Models: Application to Plant Nutrition Research. In Chemical Equilibrium and Reaction Models; Loeppert, R.H., Schwab, A.P., Goldberg, S., Eds.; SSSA and ASA: Madison, WI, 1995; SSSA Spec. Publ. 42, 163-200.

17. Parker, D.R.; Norwell, W.A.; Chaney, R.L. GEOCHEM-PC: A Chemical Speciation Program for IBM and Compatible Personal Computers. In Chemical Equilibrium and Reaction Models; Loeppert, R.H., Schwab, A.P., Goldberg, S., Eds.; SSSA and ASA: Madison, WI, 1995; SSSA Spec. Publ. $42,253-269$.

18. SAS Institute. SAS/STAT ${ }^{T M}$ User's Guide, Release 6.03 Ed.; SAS Institute, Inc.: Cary, NC, 1988.

19. Chino, M. Metal Stress in Rice Plants. In Heavy Metals Pollution in Soils of Japan; Kitagishi, K., Yamane, I., Eds.; Japan Scientific Societies Press: Tokyo, 1981; 65-80. 
20. Jones, U.S.; Katyal, J.C.; Mamaril, C.P.; Park, C.S. Wetland Rice-Nutrient Deficiencies Other than Nitrogen. In Rice Research Strategies for the Future; IRRI: Los Baños, Philippines, 1982; 327-378.

21. Tanaka, A.; Yoshida, S. Nutritional Disorders of the Rice Plant in Asia; IRRI: Manila, Philippines, 1970; Tech. Bull. 10, 51 pp.

22. Chino, M.; Baba, A. The Effects of Some Environmental Factors on the Partitioning of Zinc and Cadmium Between Roots and Tops of Rice Plants. J. Plant Nutr. 1981, 3, 203-214.

23. Honma, Y.; Hirata, H. Noticeable Increase in Cadmium Absorption by Zinc Deficient Rice Plants. Soil Sci. Plant Nutr. 1978, 24, 295-297.

24. Iimura, K.; Ito, H.; Chino, M.; Morishita, T.; Hirata, H. Behavior of Contaminant Heavy Metals in Soil-Plant System. In Proceedings of the International Seminar Soil Environment and Fertility Management in Intensive Agriculture; The Society of the Science of Soil and Manure: Japan, 1977; 357-368.

25. Obata, H.; Umebayashi, M. Effects of Cadmium on Mineral Nutrient Concentrations in Plants Differing in Tolerance for Cadmium. J. Plant Nutr. 1997, 20, 97-105.

26. Brown, S.L.; Chaney, R.L.; Angle, J.S.; Baker, A.J.M. Zinc and Cadmium Uptake by Hyperaccumulator Thlaspi caerulescens Grown in Nutrient Solution. Soil Sci. Soc. Am. J. 1995, 59, 125-133.

27. Sela, M.; Tel-Or, E.; Fritz, E.; Huttermann, A. Localization and Toxic Effects of Cadmium, Copper, and Uranium in Azolla. Plant Physiol. 1988, 88, 30-36.

28. Bell, P.F.; Chaney, R.L.; Angle, J.S. Free Metal Activity and Total Metal Concentrations as Indices of Micronutrient Availability to Barley [Hordeum vulgare (L.) 'Klages']. Plant Soil 1991, 130, 51-62.

29. McKenna, I.M.; Chaney, R.L.; Williams, F.M. The Effects of Cadmium and Zinc Interactions on the Accumulation and Tissue Distribution of Zinc and Cadmium in Lettuce and Spinach. Environ. Pollut. 1993, 79, 113-120.

30. Yang, X.; Römheld, V.; Marschner, H.; Chaney, R.L. Application of Chelator-buffered Nutrient Solution Technique in Studies on Zinc Nutrition in Rice Plant (Oryza sativa L.). Plant Soil 1994, 163, 85-94.

31. Smilde, K.W.; Van Luit, B.; Van Driel, W. The Extraction by Soil and Absorption by Plants of Applied Zinc and Cadmium. Plant Soil 1992, 143, 233-238.

32. Chaney, R.L.; Green, C.E.; Filcheva, E.; Brown, S.L. Effect of Iron, Manganese, and Zinc Enriched Biosolids Compost on Uptake of Cadmium by Lettuce from Cadmium Contaminated Soils. In Sewage Sludge: Land Utilization and the Environment; Clapp, C.E., Larson, W.E., Dowdy, R.H., Eds.; ASA, CSSA, SSSA: Madison, WI, 1993; 205-207. 
33. Choudhary, M.; Bailey, L.D.; Grant, C.A.; Leisle, D. Effect of Zn on the Concentrations of $\mathrm{Cd}$ and $\mathrm{Zn}$ in Plant Tissue of Two Durum Wheat Lines. Can. J. Plant Sci. 1995, 75, 445-448.

34. Girling, C.A.; Peterson, P.J. The Significance of the Cadmium Species in Uptake and Metabolism of Cadmium in Crop Plants. J. Plant Nutr. 1981, 3, 707-720.

35. Asami, T. Pollution of Soils by Cadmium. In Changing Metal Cycles and Hman Health; Nriagu, J.O., Ed.; Springer-Verlag: Berlin, 1984; 95-111.

36. Green, C.E.; Chaney, R.L.; Bouwkamp, J. Interactions Between Cadmium Uptake and Phytotoxic Zinc Levels in Rice (Oryza sativa L.) Using Chelator-Buffered Nutrient Solution. Plant Soil 2001, under review.

37. Fujimoto, T.; Uchida, Y. Cadmium Absorption by Rice Plants. I. Mode of Absorption. Soil Sci. Plant Nutr. 1979, 25, 407-415.

38. Rauser, W.E.; Ackerley, C.A. Localization of Cadmium in Granules Within Differentiating and Mature Root Cells. Can. J. Bot. 1987, 65, 643-646.

39. Chino, M. The Distribution of Heavy Metals in Rice Plants Influenced by the Path of Supply. J. Sci. Soil Manure 1973, 44, 204-210.

40. Herawati, N.; Rivai, I.F.; Koyama, H.; Suzuki, S. Zinc Levels in Rice and Soil According to the Soil Types of Japan, Indonesia, and China. Bull. Environ. Contam. Toxicol. 1998, 60, 402-408.

41. Wolnik, K.A.; Fricke, F.L.; Capar, S.G.; Meyer, M.W.; Satzger, R.D.; Bonnin, E.; Gaston, C.M. Elements in Major Raw Agricultural Crops in the United States. 3. Cadmium, Lead, and Eleven Other Elements in Carrots, Field Corn, Onions, Rice, Spinach, and Tomatoes. J. Agric. Food Chem. 1985, 33, 807-811.

42. Masironi, R.; Koirtyohann, S.R.; Pierce, J.O. Zinc, Copper, Cadmium and Chromium in Polished and Unpolished Rice. Sci. Total Environ. 1977, 7, 27-43.

43. Herawati, N.; Rivai, I.F.; Koyama, H.; Suzuki, S.; Lee, Y. Copper in Rice and Soils According to Soil Type in Japan, Indonesia, and China: A Baseline Study. Bull. Environ. Contam. Toxicol. 1998, 60, 266-272.

44. Lucca, P.; Wünn, J.; Hurrell, R.F.; Potrykus, L. Development of Iron-Rich Rice and Improvement of Its Absorption in Humans by Genetic Engineering. J. Plant Nutr. 2000, 23, 1983-1988. 